\title{
A new Middle-Late Jurassic flora and hot spring chert deposit from the Deseado Massif, Santa Cruz province, Argentina
}

\author{
ALAN CHANNING*, ALBA B. ZAMUNER $† \&$ ADOLFO ZÚÑIGA $†$ \\ *School of Earth, Ocean \& Planetary Sciences, Cardiff University, Main Building, Park Place, Cardiff, CF10 3 YE, UK \\ $\dagger$ Departamento de Paleobotánica, Facultad de Ciencias Naturales y Museo, UNLP, Paseo del Bosque s/n \\ 1900 La Plata, Argentina
}

(Received 14 March 2006; accepted 1 August 2006)

\begin{abstract}
We present an initial report of a well-preserved and relatively diverse Gondwanan plant assemblage from Bahía Laura Group, Chon Aike Formation strata of the Estancia Flecha Negra area, central-western region of the Deseado Massif, Santa Cruz province, Patagonia, Argentina. The locality contains the first richly fossiliferous chert with a diverse and well-preserved plant assemblage reported from the Mesozoic which is demonstrably associated with hot spring activity. A compression flora and petrified forest contained in associated clastic and volcaniclastic environments provide an indication of regional plant diversity during this as yet poorly represented stratigraphic interval.
\end{abstract}

Keywords: silicification, sinter, epithermal, permineralized, permineralised, petrified.

\section{Introduction}

The volcanic and volcaniclastic Bahía Laura Group of Santa Cruz province, Patagonia, Argentina, contains a diverse, often well-preserved and important Middle to Late Jurassic, Gondwanan flora (Table 1). To date, floras have been recorded from the tuff-dominated La Matilde Formation and occur in the northeastern region of the province, at Cerro Cuadrado-Cerro Madre e Hija and in the southeastern region, particularly in the Gran Bajo de San Julián area (e.g. Panza \& Haller, 2002). Only one flora, comprising bennettitaleans, discovered at Estancia Bajo Pellegrini (de Barrio et al. 1982), has been described from the central-western region and is attributed to the ignimbrite-dominated Chon Aike Formation.

Plant fossils are also reported from a number of hot spring-related travertine and sinter deposits contained within the Bahía Laura Group and situated in the Deseado Massif in the central-western region of the province (e.g. Marchionni et al. 1999; Guido, de Barrio \& Schalamuk, 2002; Guido et al. 2002). However, we have visited deposits at La Marcelina (Marchionni et al. 1999), El Macanudo (Schalamuk et al. 1999), La Marciana (Guido, de Barrio \& Schalamuk, 2002) and La Esperanza (Andrada de Palomera, Moreira \& Fernández, 2005) and studied hand specimens from the Marianas-Eureka-Cerro Negro area (Guido et al. 2002; Lopez et al. 2003), Cerro Contreras (Moreira et al. 2005) and La Josefina (Moreira et al. 2002) deposits. We find that at these localities, plant occurrences are rare and preservation too poor to allow taxonomic description.

\footnotetext{
*Author for correspondence: channinga@cardiff.ac.uk
}

\section{Regional geological setting}

The Deseado Massif, Santa Cruz province, Argentina, is part of a major Jurassic bimodal volcanic province, related to widespread extensional tectonism, which extends across Patagonia and Antarctica (Pankhurst et al. 1998; Riley \& Leat, 1999; Riley et al. 2001). The volcanic stratigraphy of the region is complex and has traditionally been subdivided on the basis of an evolving basaltic-rhyolitic rock geochemistry and dominant eruptive style into three formations:

Bajo Pobre Formation (Lesta \& Ferello, 1972). Andesitic and subordinate basaltic volcanic rocks forming lava domes, lava flows, debris flows, agglomerates with minor tuffs and occasional sediments.

Chon Aike Formation (Stipanicic \& Reig, 1957; Archangelsky, 1967). Rhyolitic volcanic rocks, commonly ignimbrites and lavas and less frequently agglomerates and tuffs.

La Matilde Formation (Stipanicic \& Reig, 1957; Archangelsky, 1967). Acid tuffs and bedded ash-fall deposits with less frequent ignimbrites, commonly displaying a conspicuous pink to red alteration colouration.

The latter two formations comprise the Bahía Laura Group. Local intercalation of and geochemical similarities between the andesites of the Bajo Pobre Formation and the Chon Aike ignimbrites led Echeveste et al. (2001) to revise the stratigraphy of the centralwestern region of the Deseado Massif to also include the Bajo Pobre Formation within the Bahía Laura Group. They interpreted the Bajo Pobre outcrops of the zone to represent an active effusive centre that formed a topographic high during emplacement 
Table 1. Locations, stratigraphic positions and diversity of floras previously described from the Middle to Upper Jurassic of Santa Cruz Province, Patagonia, Argentina

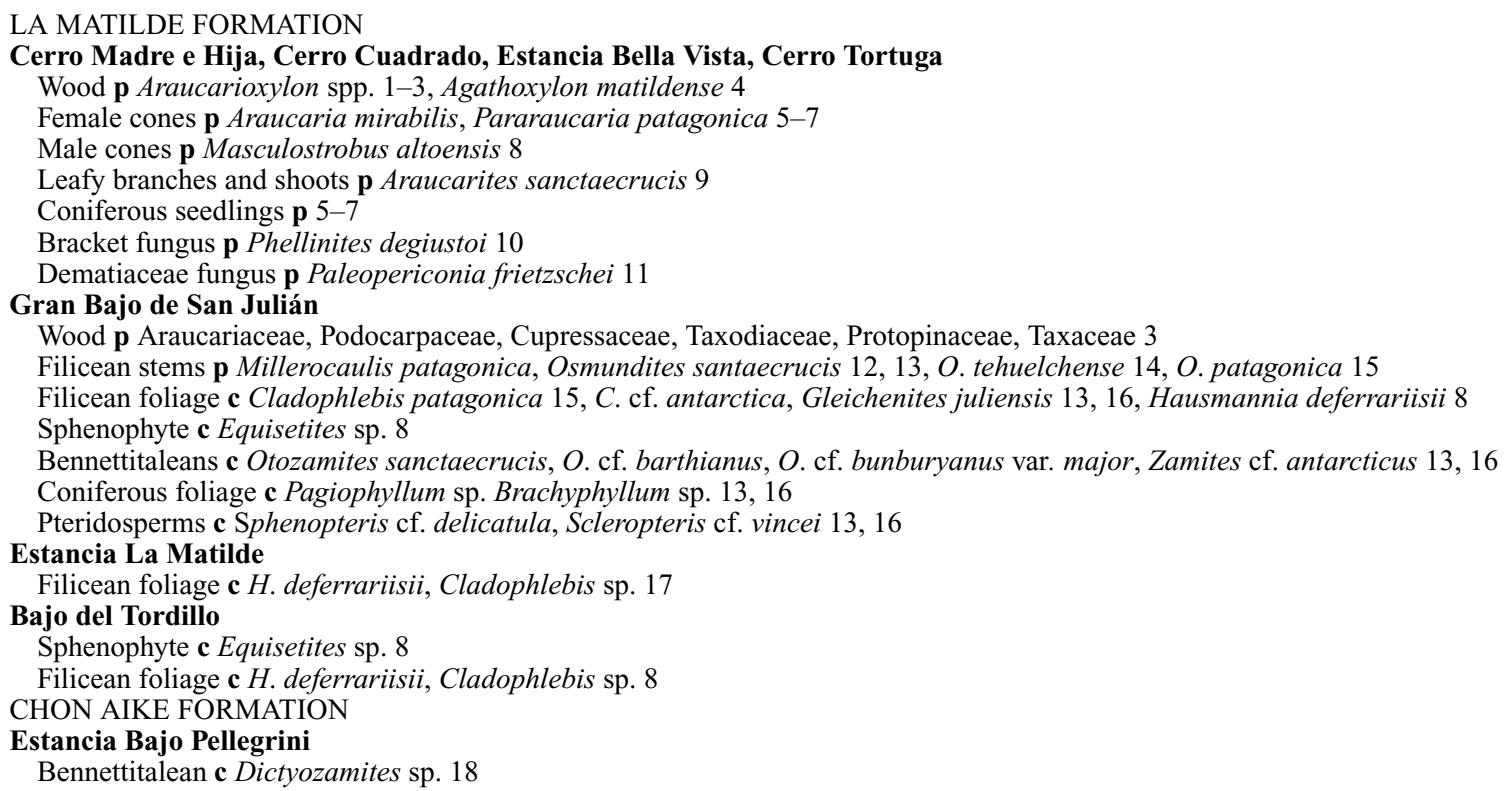

Permineralized flora $=\mathbf{p}$, Compression flora $=\mathbf{c}$

References: (1-3) Gnaedinger, 2000, 2001, 2004; (4) Zamuner \& Falaschi, 2005; (5-7) Stockey, 1975, 1977, 1978; (8) Panza \& Haller, 2002; (9) Calder, 1953; (10) Hibbett, Donoghue \& Tomlinson, 1997; (11) Ibáñez \& Zamuner, 1996; (12) Herbst et al. 1995; (13) Herbst \& Salazar, 1998; (14) Herbst, 2003; (15) Archangelsky \& de la Sota, 1962; (16) Archangelsky \& Archangelsky, 2002; (17) Stipanicic \& Reig, 1957;

(18) de Barrio et al. 1982.

of the Chon Aike ignimbrites. Geothermal activity accompanied volcanism in the region, and recent mineral exploration activity in the Deseado Massif has revealed the presence of numerous epithermal systems and terrestrial hot spring sinter and travertine deposits (e.g. Schalamuk et al. 1997; Echavarría, Schalamuk \& Etcheverry, 2005).

\section{Locality and local geology}

\section{3.a. Locality details}

Laguna Flecha Negra $\left(69^{\circ} 48^{\prime} 7.52^{\prime \prime} \mathrm{W}-47^{\circ} 55^{\prime} 13.88^{\prime \prime} \mathrm{S}\right)$ is situated approximately $100 \mathrm{~km} \mathrm{NNE}$ of Gobernador Gregores, Santa Cruz Province, Argentina (Fig. 1a) and is accessed from a minor road that leads NW towards Estancia Flecha Negra from the Dos ManantialesBajo Caracoles Road approximately $10 \mathrm{~km}$ north of the Estancia El Fénix.

\section{3.b. Local geology}

The Laguna Flecha Negra flora is contained in fluvial sediments, chert beds and rhyolitic tuffs. The basal fluvial sequence was deposited above a landscape unconformity developed on the weathered and eroded surface of a Bajo Pobre Formation andesitic dome complex. The top of the sequence is covered to the north and west by the youngest Chon Aike Formation ignimbrite sheet in the area called the Ignimbrita Flecha Negra (Echeveste et al. 2001). We therefore consider the strata to be an easterly extension of the Tobas de Caída El Fénix unit of the Chon Aike Formation mapped by Echeveste et al. (2001).

\section{3.b.1. Bajo Pobre Facies, lava dome complex (Fig. 1, BPA)}

The oldest rocks of the Laguna Flecha Negra area are lavas that form part of a major andesitic dome complex. Mapping of the area reveals the presence of a landscape unconformity with high ground to the east and low ground at the site of the present lake. To the east of the laguna the lavas contain angular xenoliths of more basic lava, while to the west they appear massive and lack xenoliths. At the western margin of the lava outcrop, widespread alteration ranging from degraded biotites to broad areas of degraded lava fragments with bluegreen colouration is apparent. Intense weathering at the margins of the outcrop produces a structurally unstable and friable, but in situ white, orange-red weathering residue.

\section{3.b.2. Chon Aike Formation - Tobas de Caída El Fénix, fluvial sequence}

The clastic sequence is exposed in the shore and low cliffs surrounding Laguna Flecha Negra (Fig. 1c). Basal sediments of the unit which lie directly above the Bajo Pobre Lavas (Fig. 1b) are massive to thickly bedded, white to mottled orange weathering, coarse sands. These comprise angular volcanic lithic clasts and crystals and weathered feldspars which indicate 


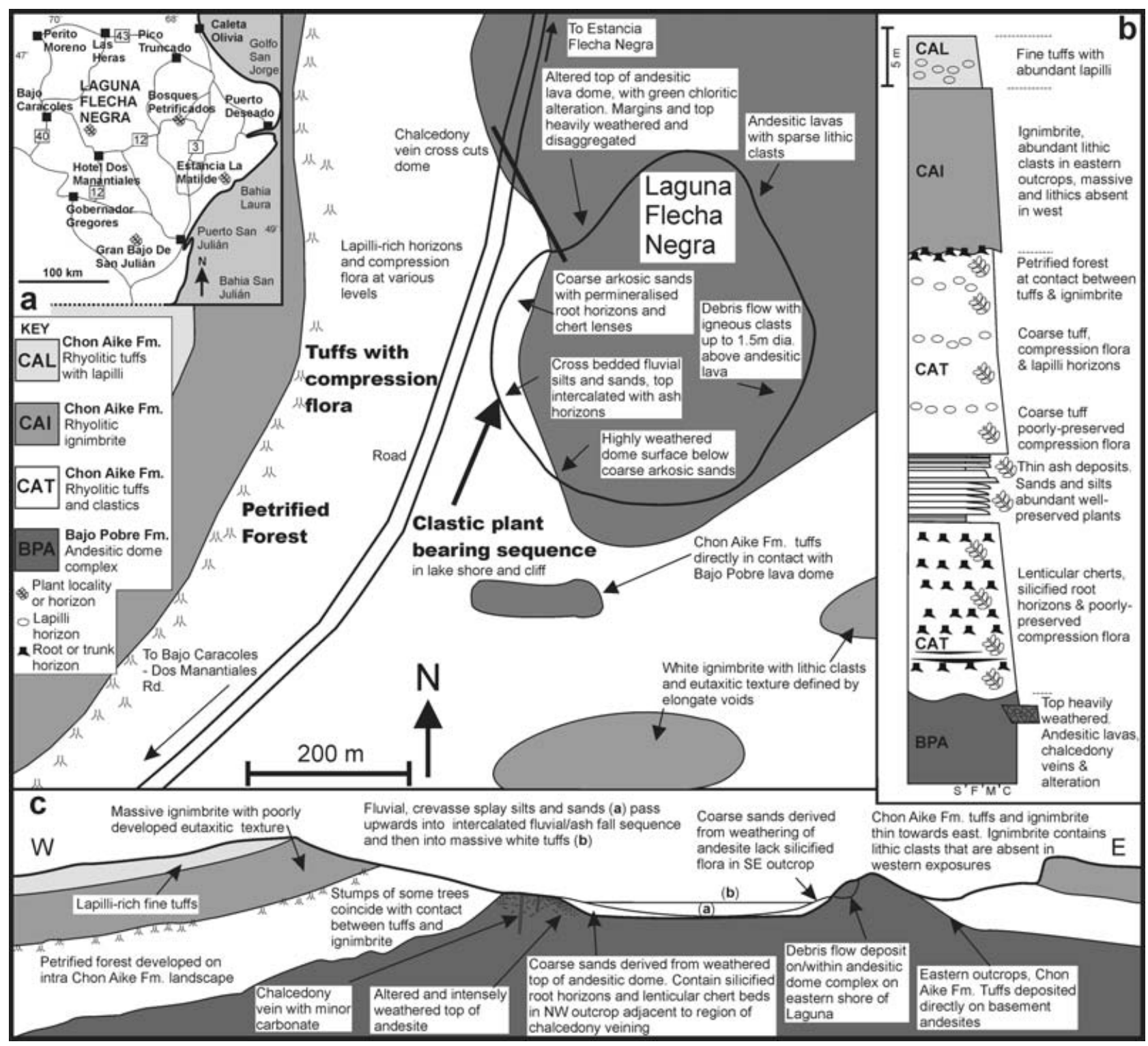

Figure 1. (a) Location map and sketch geological map, (b) lithological log and (c) cross-section for the Laguna Flecha Negra locality.

a proximal sediment source and derivation from the underlying highly weathered Bajo Pobre lavas. The sandstone sequence, which is about $35 \mathrm{~m}$ thick, fines upwards, becomes more thinly bedded and comprises more quartz-rich, mature sediment. Individual beds within the unit are conglomeratic and contain sandstone intra-clasts up to $4 \mathrm{~cm}$ in diameter. Contained within the coarse sandstone strata on the northwest shore of the laguna is a sequence of petrified root horizons and lenticular chert horizons (Fig. 2). On the southeastern shore, similar sediments are devoid of silicified horizons, indicating an apparent geographic restriction of the influence of silicifying fluids.

Conformably overlying the sandstones are approximately $5 \mathrm{~m}$ of beige-brown to olive green weathering sands and silts. The base of the unit begins with thinly bedded $(1-3 \mathrm{~mm})$ dark grey to beige-green weathering silts which are parallel bedded and fissile. These contain a poorly preserved but identifiable compression flora. In the overlying strata, bed thickness increases to $10-35 \mathrm{~mm}$. Each bed represents an upward-fining sand to silt transition with initial cross-bedding giving way to parallel bedding. Bedding surfaces may contain relatively coarse, heavily weathered, volcanic clasts, degraded ash particles and mica flakes. Concentrations of bedding-parallel elliptical voids mark horizons containing a well-preserved compression flora (Fig. 3). The top of the unit shows increasing evidence of explosive volcanism in the region as sand-silt beds become intercalated with initially thin $(5-10 \mathrm{~mm})$ but thickening white weathering ash horizons. The contact between the clastic sequence and overlying massive tuffs is obscured throughout the mapped area by base-of-slope scree deposits. Apparent dips, however, suggest that the two units are relatively conformable. 

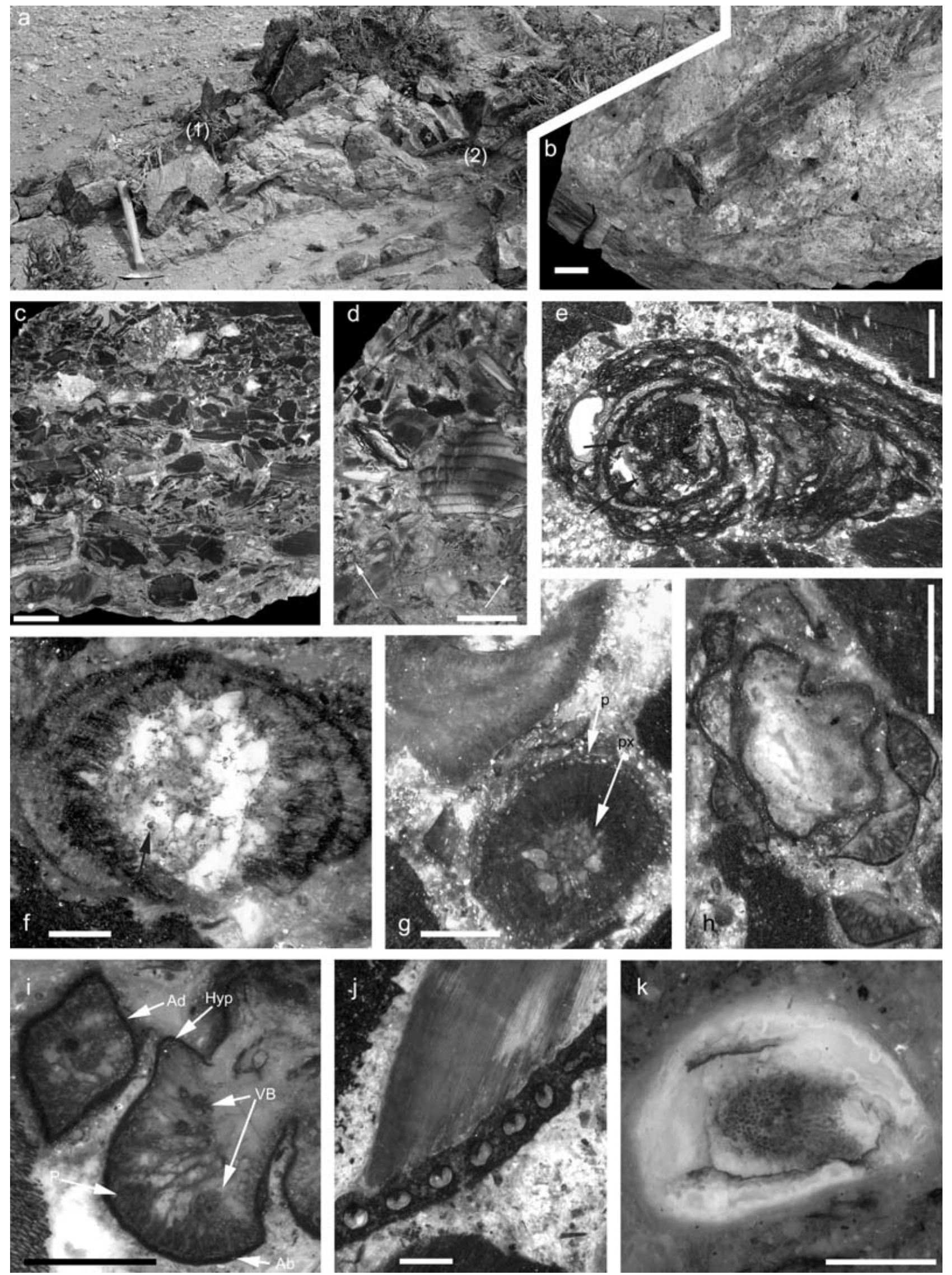

Figure 2. For legend see facing page. 

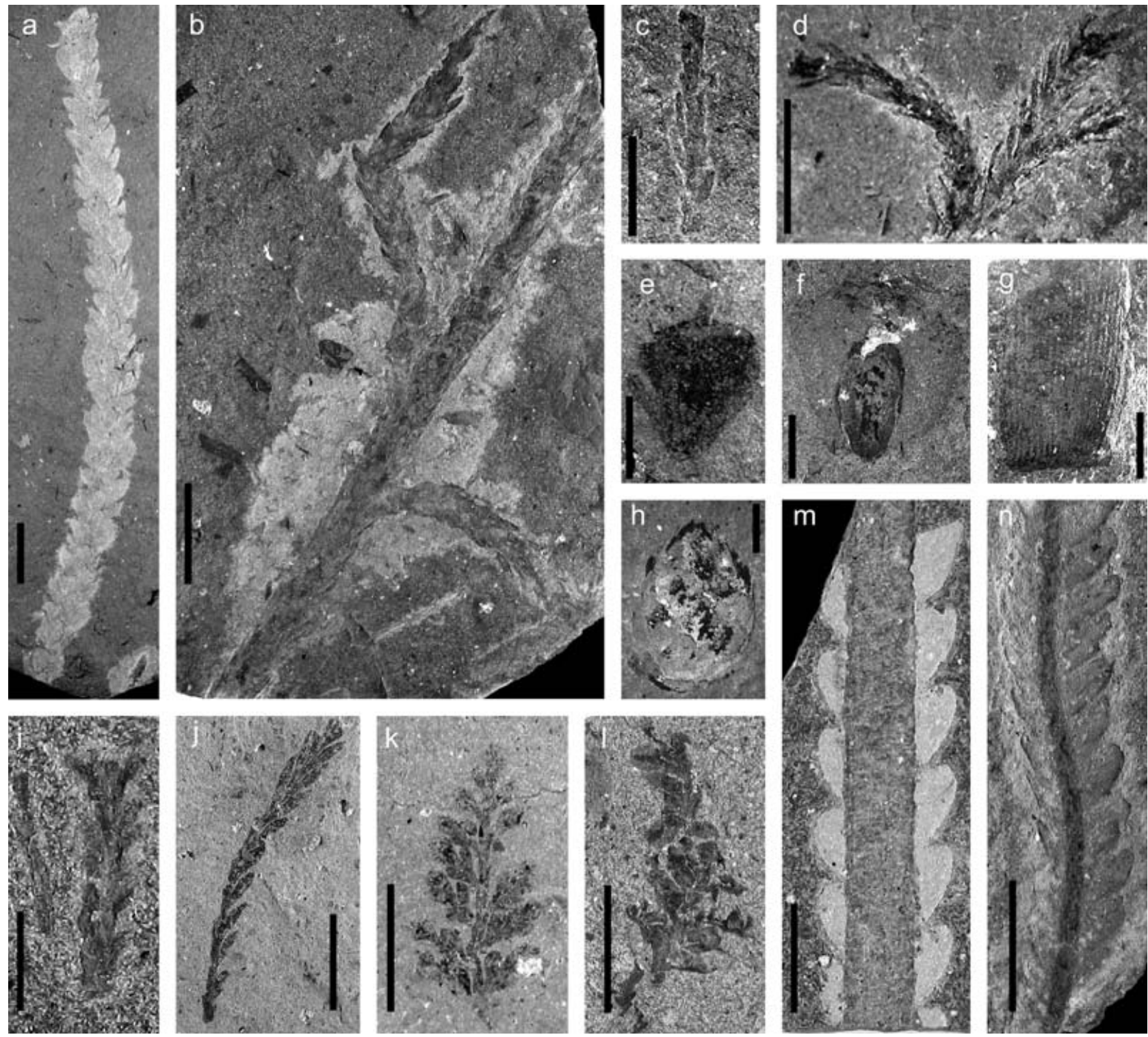

Figure 3. Typical elements of the compression flora contained in fluvial sediments cropping out on the west shore of Laguna Flecha Negra. (a, b) Foliage and branches of Brachyphyllum sp. Scale bars: (a) $1 \mathrm{~cm}$; (b) $2 \mathrm{~cm}$ (c, d) Leafy shoots of Pagiophyllum sp. Scale bars: (c) $9 \mathrm{~mm}$; (d) $8 \mathrm{~mm}$. (e, f) Dispersed mature seed scales of Araucarites sp. Scale bars: (e) $1 \mathrm{~cm}$; (f) $6 \mathrm{~mm}$. (g) Pinnae of cycadophyte with parallel venation. Scale bar: $1 \mathrm{~cm}$. (h) Cone of conifer with poorly preserved helically arranged sporophylls. Scale bar: $5 \mathrm{~mm}$. (i,j) Elatocladus sp. foliage. Scale bars: (i) $5 \mathrm{~mm}$; (j) $1 \mathrm{~cm}$. (k) Sphenopteris sp. frond, apical fragment. Scale bar: $1 \mathrm{~cm}$. (l) Probable pinnate pteridosperm, reproductive structure. Scale bar: $1.3 \mathrm{~cm} .(\mathrm{m}, \mathrm{n})$ Monopinnate fronds of bennettitaleans, Otozamites sp. (m) basal region and (n) mid-frond. Both exhibit cuticular preservation. Scale bars: (m) $1 \mathrm{~cm}$; (n) $1.5 \mathrm{~cm}$.

Figure 2. Chert horizon and permineralized flora. (a) Lenticular chert bed (1) split horizontally at level of sandstone parting, above permineralized root and stump horizon (2) within coarse, bedded sandstone sequence. Sandstone beds deflect around stump base. Hammer shaft length is $35 \mathrm{~cm}$. (b) Permineralized ramified roots within coarse sand. Scale bar: $1 \mathrm{~cm}$. (c) Vertical section through chert bed with abundant wood fragments, shoots and roots. Scale bar: $1 \mathrm{~cm}$. (d) Horizontal section through chert horizon, angular wood fragments with prominent growth-rings and small, vertically orientated plant axes (arrows). Scale bar: $1.5 \mathrm{~cm}$. (e) Conifer root with diarch protostele structure (arrows). Scale bar: $1 \mathrm{~mm}$. (f) Transverse section through permineralized conifer stem with two growth-rings and patchily-preserved parenchymatous cells in the pith. Spherical fungal spores occur within regions of degraded tissue (arrows). Scale bar: $1 \mathrm{~mm}$. (g) Transverse section through conifer stem with well-preserved pith and endarch protoxylem (px) and phloem (p). Adjacent permineralized scale leaf has well-preserved palisade parenchyma. Scale bar: $1 \mathrm{~mm}$. (h) Permineralized shoot of araucarian-type with spirally arranged leaves exhibiting preservation of parenchymatous tissues. Scale bar: $1 \mathrm{~mm}$. (i) Transverse and oblique section through scale leaves of araucarian-type. Abaxial surface with thick cuticle (Ab), hypodermis (Hyp), palisade parenchyma (P) and vascular bundles (VB). Adaxial surfaces (Ad) lack thick cuticle and palisade parenchyma. Scale bar: $1 \mathrm{~mm}$. (j) Transverse section through cycadophyte leaf with partially preserved vascular bundles. Scale bar: $1 \mathrm{~mm}$. (k) Transverse section through a conifer seed with embryonic tissue. Scale bar: $1 \mathrm{~mm}$. 

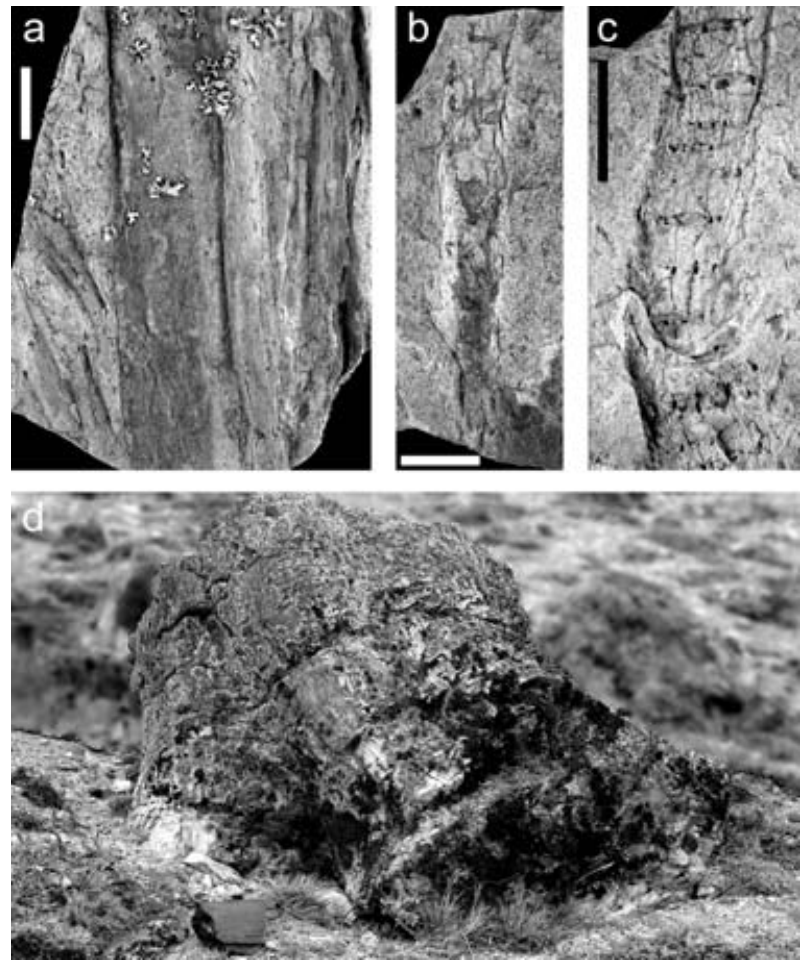

Figure 4. Typical elements of the permineralized and compression flora in the Chon Aike Formation - Tobas de Caída El Fénix Tuffs (CAT). (a) Decorticated branch. Scale bar: $1 \mathrm{~cm}$. (b) Brachyphyllum sp. branch with poorly preserved scale leaves. Scale bar: $1 \mathrm{~cm}$. (c) Sphenophyte stem with whorled leaf scars. Scale bar: $1 \mathrm{~cm}$. (d) Permineralized stump (about $1.5 \mathrm{~m}$ diameter) in growth-position on inclined substrate. Largest of the massive lateral roots (about $1 \mathrm{~m}$ diameter) points downhill towards bottom right of image.

\section{3.b.3. Chon Aike Formation - Tobas de Caida El Fénix, tuff (Fig. 1, CAT)}

The contact between the thick white tuff sequence and underlying strata is marked to the east of Laguna Flecha Negra by a landscape unconformity above Bajo Pobre lavas and to the west by an apparently conformable contact with the underlying clastic sequence. The tuffs are poorly bedded, internally massive and white to pink altered and/or weathered. The sequence comprises alternations of coarse tuff units that fine upwards and thinner lapilli-rich tuff horizons. The overall character of the unit fines upwards. The tuff sequence is fossiliferous, containing plant compression fossils throughout (Fig. 4a-c). The top of the tuff has a well-preserved and widespread (extending about $1 \mathrm{~km}$ ) petrified forest horizon developed on a sloping palaeotopography (Fig. 4d).

\section{3.b.4. Chon Aike Formation - Tobas de Caída El Fénix, Ignimbrite (Fig. 1, CAI)}

A pink, beige weathering welded rhyolitic ignimbrite forms a conspicuous cap on many hills of the area. The base of the ignimbrite is marked by a change of slope which is normally masked by deposits of scree derived from cliffs above which form the top of the ignimbrite. However, in places the ignimbrite is seen to sit on an uneven surface developed on the underlying tuffs. In places the contact between tuff and ignimbrite coincides with the in situ and in growth position stumps of petrified trees. Texturally, the ignimbrite is generally welded and massive, but a poorly defined eutaxitic texture is defined by open pockets with sub-horizontal long axes. In the east of the mapped area, volcanic lithic clasts, commonly of darker rhyodacitic volcanic rocks, are also incorporated in the ignimbrite.

\section{3.b.5. Chon Aike Formation - Tobas de Caida El Fénix, lapilli tuff (Fig. 1, CAL)}

The youngest rocks of the area are bright-white, bedded $(10-60 \mathrm{~mm})$ fine-grained tuffs. Beds appear internally homogeneous but contain abundant spherical to ellipsoidal accretionary lapilli with diameters of about 5-10 $\mathrm{mm}$.

\section{3.b.6. Cross-cutting mineralization}

On the west shore of Laguna Flecha Negra, crosscutting chalcedony veining with minor carbonate occurs at a number of levels at the margin/top of the altered and weathered Bajo Pobre lavas (Fig. 1a). Poor exposure prevents confirmation of whether the veining cross-cuts the basal clastic sediments, and the relationship between cross-cutting chert veins and conformable chert lenses and silicified root horizons. However, Laser Mass Spectroscopy reveals that the matrix chert of both vein material and chert beds contains anomalous concentrations of $\mathrm{As}, \mathrm{Sb}$ and $\mathrm{Tl}$ (Table 2). Hg concentrations in vein and chert bed samples, obtained by Analytical Scanning Electron Microscopy were between 0.09 and $0.84 \mathrm{wt} \%$. The vein chert contains disseminated micron- to millimetrescale inclusions of iron oxides or hydroxides after framboidal and euhedral pyrite; these variously have associated trace element concentrations of $\mathrm{Mn}, \mathrm{Ti}, \mathrm{W}$ and V. Trace concentrations of $\mathrm{Na}, \mathrm{Cl}, \mathrm{K}, \mathrm{Ca}$ and $\mathrm{Mg}$ are also associated with both vein and bedded cherts.

\section{Flora and floral associations}

\section{4.a. Compression flora and silicified root horizons in coarse sandstones}

Massive coarse sandstones at the base of the clastic sequence on the west shore of Laguna Flecha Negra appear devoid of plant fossils. Overlying bedded coarse sandstones contain poorly preserved compressions and external moulds of gymnosperm roots or branches plus rare silicified plant fragments which lack cellular preservation and are not taxonomically identifiable.

Six root horizons occur within the coarse-sandstone unit (Fig. 1b). Each horizon comprises a network of large $(5-20 \mathrm{~cm})$ diameter dichotomizing roots that 
variously appear to be conformable with and crosscut the sediment matrix (Fig. 2a, b). The larger roots are accompanied by smaller permineralized roots of millimetre- to centimetre-scale in a partially silicified sandstone matrix. Preservation of the root tissues is extremely good; axes exhibit little or no distortion of their original shape and growth rings are easily discernable. One root horizon has an exposed major root several metres long and $15-20 \mathrm{~cm}$ diameter, while another contains a trunk base with a diameter of about $50 \mathrm{~cm}$ (Fig. 2a). These obviously represent relatively mature vegetation and hiatuses in volcanic and sedimentary deposition processes long enough for sere development.

\section{4.b. Lenticular chert horizons within coarse sandstones}

Two lenticular chert horizons occur within the same strata as the silicified root horizons. The lower chert is approximately $8 \mathrm{~m}$ in diameter and up to $30 \mathrm{~cm}$ thick. At the thickest point the lens becomes a composite of two chert layers separated by a sandstone parting (Fig. 2a). The base of the chert is in contact with the top of a large silicified trunk base and root system in the bed below (Fig. 2a). The chert lens has an uneven contact with underlying sediments. Internally, initial sediments are finely laminated silts/mudstones containing compressed plant remains. Above, a matrix of sandstone which fines upwards supports angular to rounded clasts of silicified wood, which are aligned with their long axes parallel to the lens base or with slight imbrication (Fig. 2c). The percentage of matrix versus wood clasts and wood clast-size generally decrease upwards through the middle of the bed, and the wood becomes clast-supported. Interstitial matrix becomes a clear to clotted chert with little sign of clastic material but an abundance of disseminated and finely comminuted organic particles, microbial filaments, plant and microbial spores and bisaccate conifer pollen. Towards the top of the bed, larger wood fragments once again become abundant, but the ratio of matrix to organic clasts remains low. The top surface of the chert lens is crowded with millimetre- to centimetre-scale wood fragments. Overall the chert has a black colour, derived from the abundant silicified wood fragments within the bed.

A spectrum of wood preservation quality is seen within the chert. Poorly preserved material has degraded to the point of fibre separation and was permineralized after a phase of plastic deformation and vertical compression and collapse. Good preservation allows observation of well-defined 1-3 mm thick growth-rings with poorly developed latewood (Fig. 2d), homogeneous, low and mainly uniseriate parenchymatous rays, bordered pits, and the absence of resiniferous channels.

In addition to degraded and transported wood, young in situ permineralized conifer roots and stems with diameters of up to $5 \mathrm{~mm}$ are distributed throughout the lens. Some roots have a diarch protostele, cortex and poorly developed secondary tissues (Fig. 2e). Permineralization of the stem tissues extends to the parenchymatous cells of the pith (Fig. 2f, g), phloem and cortex (Fig. 2g). Degraded areas of parenchyma within the pith of some stems contain fungal hyphae and spores (Fig. 2f). Surrounding the pith, primary xylem shows eustelic arrangement of bundles (Fig. 2f, g). Shoots of conifers with attached leaves, which were preserved in a horizontal position within the chert lens (Fig. 2h, i), illustrate that parts of the permineralized flora had undergone relatively little transport and were probably autochthonous or para-autochthonous. Disseminated organs within the chert include conifer shoots with scale leaves of Brachyphyllum-Pagiophyllum morphology (Fig. 2g-i), cycadophyte (cycad or bennettitalean) leaves (Fig. 2j) and possible conifer seeds (Fig. 2k). Conifer leaves have a rhomboidal-lanceolate outline and a broad base (Fig. 2g-i); anatomical features visible in these include vascular bundles with well-developed centripetal metaxylem, thick abaxial and thin adaxial cuticle and a hypodermis with one or two layers (Fig. 2i). Parenchymatous structures include palisade and spongy parenchyma (Fig. $2 \mathrm{~g}-\mathrm{i}$ ). In combination these characters suggest an araucarian affinity. Cycadophyte leaves also occur frequently. Transverse crosssections through the leaves show thin blades of about $0.7 \mathrm{~mm}$ thickness, with several vascular bundles of more or less circular shape and about $0.5 \mathrm{~mm}$ diameter within a homogeneous mesophyll (Fig. 2j). Regions of embryonic tissue are visible within less common, mature seeds (Fig. 2k). Leafy shoots (Fig. 2h, i), leaves (Fig. 2g, j) and seeds (Fig. 2k) have regions of wellpreserved parenchyma despite, in the case of the leaves and seeds, having undergone a period of transport and burial. These illustrate that permineralization and formation of the chert was extremely rapid and must have occurred very quickly after deposition and/or accumulation of the organic components.

A second thinner chert, about $5 \mathrm{~cm}$ thick and 3$4 \mathrm{~m}$ in diameter, occurs $70 \mathrm{~cm}$ above the main chert lens (Fig. 1b). This has rippled upper and lower contacts with coarse sandstone beds. The base and top of the lens comprise fining-upwards sequences of silicified sandstone containing plant compressions. Only the central $3 \mathrm{~cm}$ of the lens have a clear to clotted chert matrix, and this contains clast-supported permineralized wood fragments, roots, stems, cones and spores. Axial organs within the lens were generally less well-preserved than those in the main chert, generally comprising cylindrical to compressed cuticular or epidermal straws with completely degraded cortical tissues. Further evidence of lower plant preservation in the environment represented by this lens is provided by wood fragments which appeared to have margins with a high degree of de-lignification. 


\section{4.c. Compression flora in fluvial sands and silts}

The basal parallel-bedded sands and silts of this unit contain abundant but fragmentary carbon compressions and poorly preserved compressed coniferous branches. Above, in finer sediments, plant preservation is better and species diversity greater. Conifers are the dominant component of the compression flora and are represented by two different types of foliaceous branches with helically arranged, lanceolate, adpressed leaves (Fig. 3a-d) and the dispersed ovuliferous scales of Araucarites sp. (Fig. 3e, f). Foliage with at least two orders of branches in organic connection was common (Fig. 3b, d). The dominant coniferous foliage is assignable to the Brachyphyllum sp. (Fig. 3a, b) with less frequent occurrence of Pagiophyllum sp. (Fig. 3c, d). We speculate on the basis of foliar morphology and the association of the foliage with araucarian seeds that the community was dominated by this group. Less common elements of the flora were large cycadophyte (cycad or bennettitalean) pinnules (Fig. 3g), small (about $1 \mathrm{~cm}$ diameter) ovalcircular conifer strobili with helically arranged sporophylls (Fig, 3h), foliaceous Elatocladus sp. branches (Fig. 3i, j), pteridosperm fronds of Sphenopteris type (Fig. 3k) and pinnate pteridosperm-like reproductive structures (Fig. 31). Fragments of the monopinnate fronds of Otozamites sp. (Fig. $3 \mathrm{~m}, \mathrm{n}$ ) were relatively common within individual horizons, where they occurred in association with BrachyphyllumPagiophyllum foliage and ovuliferous scales of Araucarites. Many of the bennettitalean fronds had well-preserved regions of cuticle.

\section{4.d. Compression flora and petrified forest in Chon Aike Formation tuffs}

In the coarse Chon Aike Formation tuffs, plant preservation was common but preservation quality poor and apparently limited to relatively robust plant axes and branches (Fig. 4a-c). The flora comprised cf. Brachyphyllum sp. branches with variable levels of preservation extending from decorticated branches to branches with attached but poorly preserved scale leaves (Fig. 4a, b) and poorly preserved sphenophyte stems with whorled leaf scars (Fig. 4c).

Petrified tree trunks (Fig. 4d) occurred in the upper part of the tuff sequence, either at three different stratigraphic levels or within a single interval on an exhumed Jurassic hill slope (Fig. 1). The forest comprises large coniferous trees with trunk diameters in the range $0.28-2.20 \mathrm{~m}$ (average $1.5 \mathrm{~m}, \mathrm{n}=30$ ). The forest contains in excess of fifty individual trees. Frequently they are represented by stumps in life position, and with major root orientations that indicate their growth on an inclined surface (Fig. 4d). Tree stumps are distributed between 5.5 and $36 \mathrm{~m}$ apart. The stump density and the different classes of trunk diameter suggest that the forest represents a mature community, commonly with a high density of individuals. The topographically highest in situ tree stumps appear to coincide with the contact between the tuff sequence and overlying ignimbrite. Additionally, many fallen trunks have a common NNW-SSE alignment. In combination, these observations may suggest the forest's destruction in a single event associated with emplacement of the overlying ignimbrite sheet. As with the silicified root horizons, the development of mature vegetation indicates relatively protracted hiatuses in volcanic activity in the area.

\section{Discussion}

\section{5.a. Sedimentary environments}

The massive basal sediments above the landscape unconformity show little evidence of transport and apparently derive from the altered, hydrothermally bleached and weathered top of the Bajo Pobre lavas below. We interpret this initial clastic sequence to represent deposits associated with basin margin alluvial fans. The bedded coarse sandstones which pass upwards into fissile silts-muds and repeated sequences of cross-laminated sand and silt suggest the initial development of a braided stream and subsequent development of a meandering stream in an alluvial plain setting. The numerous silicified root horizons and chert lenses with abundant transported and in situ plant material within the bedded sandstones indicate repeated migration and occasional abandonment of channels and formation of standing water pools. During hiatuses in deposition, relatively mature vegetation colonized sediment surfaces. Sedimentation in the alluvial plain environment was dominated by the development of crevasse-splay deposits and subsequently a switch from fluvial sedimentation to subaerial volcanism.

\section{5.b. Origin of the Laguna Flecha Negra cherts}

The Deseado Massif has abundant evidence of lowsulphidation epithermal systems, many of which have associated surficial sinter and travertine deposits (e.g. Schalamuk et al. 1997). Plant fossils have been reported from a number of these environments (Marchionni et al. 1999; Guido, de Barrio \& Schalamuk, 2002; Guido et al. 2002), but fossils are sparse and preservation quality too low to allow anatomical and taxonomic description. Two processes may be responsible for the lack of informative plant fossils. Firstly, the hot spring environments thus far described in the Deseado Massif are proximal sinter and travertine mounds and aprons (Guido, de Barrio \& Schalamuk, 2002; Guido et al. 2002; Andrada de Palomera, Moreira \& Fernández, 2005) which present harsh environments for plants, dictating an initial low plant diversity and abundance. Secondly, the subaerial surfaces of aprons 
Table 2. Concentrations of elements (in ppm) considered to be potential indicators of low-sulphidation epithermal Au/Ag and hot spring $\mathrm{Au} / \mathrm{Ag}$ deposits in samples of Laguna Flecha Negra and selected Palaeozoic hot spring chert deposits

\begin{tabular}{|c|c|c|c|c|c|c|c|c|c|c|c|c|c|c|c|c|}
\hline & $\mathrm{Li}$ & B & $\mathrm{Mn}$ & $\mathrm{Ni}$ & $\mathrm{Cu}$ & $\mathrm{Zn}$ & As & Mo & $\mathrm{Ag}$ & $\mathrm{Sn}$ & $\mathrm{Sb}$ & $\mathrm{Ba}$ & W & $\mathrm{Au}$ & $\mathrm{Tl}$ & $\mathrm{Pb}$ \\
\hline LFNV & 64.0 & 16.9 & 23.2 & 69.1 & 5.70 & 0.62 & 5.9 & 0.2 & n.d. & 1.2 & 2.1 & 0.7 & 0.8 & n.d. & n.d. & 0.18 \\
\hline LFNC1 & 61.7 & 13.6 & 15.0 & 91.0 & 5.35 & 0.92 & 6.8 & 0.2 & 0.04 & 1.2 & 1.7 & 10.0 & n.d. & n.d. & 0.004 & 0.08 \\
\hline LFNC2 & 64.7 & 18.4 & 31.9 & 115.9 & 23.2 & 8.59 & 11.5 & 0.1 & 0.19 & 1.8 & 0.8 & 1572.9 & 0.1 & 0.001 & 0.455 & 3.68 \\
\hline WOB & 67.8 & 9.4 & 14.5 & 89.9 & 4.36 & 0.54 & 3.5 & 0.1 & 0.03 & 1.2 & 33.1 & 21.5 & 2.5 & 0.009 & 0.023 & 0.36 \\
\hline $\mathrm{RCH}$ & 52.7 & 14.9 & 13.9 & 105.3 & 4.35 & 0.72 & 2.9 & 0.2 & 0.02 & 1.2 & 2.0 & 6.3 & n.d. & n.d. & 0.017 & 0.04 \\
\hline WCH & 118.9 & 4.6 & 27.8 & 99.5 & 5.82 & 1.48 & 3.8 & 0.2 & 0.01 & 1.2 & 4.5 & 112.5 & 0.1 & 0.009 & 0.029 & 0.72 \\
\hline
\end{tabular}

Samples: Laguna Flecha Negra chalcedony vein (LFNV), Laguna Flecha Negra chert (LFNC1 and LFNC2), Wobegong sinter, Drummond Basin, Queensland, Australia (WOB), Rhynie Chert (RCH) and Windyfield Chert (WCH), Aberdeenshire, Scotland. Analyses were conducted by Laser Ablation Mass-Spectroscopy utilizing a New Wave Research UP213 ultraviolet laser (213 nm) coupled to a Thermo X7 ICP-MS system. Spot analyses were conducted with the following parameters: laser frequency $-20 \mathrm{~Hz}$, laser power $-0.47 \mathrm{~mJ}$ per pulse ${ }^{-1}$, beam diameter $-80 \mu \mathrm{m}$, acquisition time -70 seconds. Element concentrations were calculated from calibration curves based on NIST standards 610, 612 and 614 analysed under identical conditions to the unknowns.

provide relatively low preservation potentials for plant tissues, particularly parenchymatous tissues, as they are intermittently drying environments with relatively low vertical accretion rates (e.g. Channing \& Edwards, 2004). We hypothesize that in contrast, the Laguna Flecha Negra plant-rich chert lenses formed in a distal, low temperature, ephemeral or emergent aquatic setting. We base this hypothesis on features that the cherts share with the richly fossiliferous Devonian hot spring cherts of Rhynie and Windyfield, Aberdeenshire, Scotland:

(1) Both deposits occur within an alluvial environment close to basin margin sediment sources associated with an andesitic-rhyolitic volcanic terrain.

(2) Both deposits are closely associated with areas of cross-cutting chalcedony \pm calcite veins, containing disseminated iron oxides after pyrite and elevated concentrations of $\mathrm{As}, \mathrm{Hg}$ and $\mathrm{W}$ (Baron et al. 2004).

(3) Initial Laser Mass Spectrometer analyses of Laguna Flecha Negra and Rhynie/Windyfield chert samples (Table 2), plus comparison of element concentrations with other sinter deposits of the Deseado Massif (e.g. Guido, de Barrio \& Schalamuk, 2002), reveal closely comparable trace element 'fingerprints'. Both chalcedony veins and chert beds show enrichment of elements typically associated with low sulphidation epithermal Au-Ag (Panteleyev, 1996b) and hot spring Au-Ag deposits (Panteleyev, 1996a).

(4) Chert bed morphology matches the commonly lenticular to podiform and composite-lens structures of Rhynie/Windyfield and indicates deposition in hollows in the surface of active alluvial fan deposits.

(5) Texturally, the chert beds comprise sandstones with undulose or rippled bases containing compacted organic material and plants preserved as hollow straws, which pass upwards into massive chert which is rich in three-dimensionally preserved plants. In detail, matrix chert in the massive chert layers comprises amorphous organic-rich clots plus degraded but identifiable phytodebris (microscopic wood fragments and cuticle), spores/pollen and microbial filaments. These features compare closely with the lenticular and massive chert facies of Rhynie (Trewin, 1994, 1996) and Windyfield (Fayers \& Trewin, 2004).

(6) Palaeontological and taphonomic similarities include the preservation of fleshy parenchymatous tissues and organs in three dimensions and at the cellular level and preservation of a bacterial and fungal micro-biota. Additionally, all three cherts contain a mix of allochthonous, paraautochthonous and in situ plant materials that exhibit a spectrum of levels of degradation from preservation of entire tissues/organs to collapsed cuticular straws.

\section{Significance}

The Laguna Flecha Negra locality greatly expands the recorded plant diversity of the Chon Aike Formation and illustrates plant diversity associated with proximal volcanic settings within the region's broader volcanic terrain. The locality contains, at the family level, all of the higher plant diversity thus far reported from the Jurassic of Patagonia. Repeated colonization and sere development is evident at the locality, which demonstrates the punctuation of local volcanic activity by hiatuses spanning hundreds to thousands of years.

Comparison of the geological setting and initial investigations of sedimentary fabrics and geochemical characteristics of the Laguna Flecha Negra cherts suggest their formation at the surface in shallow depressions containing organic-rich sediments as geothermal fluids, derived from hot springs, flowed across the surface of an alluvial plain. To our knowledge, this locality contains the first richly fossiliferous chert beds discovered in the Deseado Massif and the first Jurassic and Mesozoic hot spring deposit with a 
well-preserved flora. The ecosystem contained in the Rhynie Chert underpins much of our understanding of early terrestrial ecosystems. Similarly, this chert has enormous potential significance as it contains plant groups and plant organs and tissues, which in most environments have a low preservation potential, preserved in three dimensions and at the cellular level. The presence of previously unreported 3-D organs, including young roots and stems, mature leaves and leafy shoots with leaf primordia, plus the presence of reproductive structures and an abundance of wood material, offers the opportunity to study plant histology, anatomy, developmental biology, ecological adaptations, habit, branching system, and evolution of Jurassic taxa and floras in Gondwanaland.

The Laguna Flecha Negra area contains a permineralized chert flora, fossil forest silicified in growth position and compression floras with cuticular preservation within a laterally and stratigraphically compact area. The juxtaposition of sites that include many different types of plant preservation, allied with exceptional preservation quality, high botanical diversity and high fossil abundance, make the area unique. The association of plant-bearing clastic and volcaniclastic sequences and hot spring deposits make the area ideally suited to ongoing taphonomic and palaeoecological investigations that could address questions relating to the role of adaptation-preadaptation, specialization and endemism of hot spring floras (e.g. Channing, 2003).

\section{References}

Andrada De Palomera, P., Moreira, P. \& Fernández, R. 2005. Manifestaciones de tipo 'hot spring' asociadas al volcanismo Jurásico del área La Esperanza Oeste, Macizo del Deseado, Provincia de Santa Cruz. XVI Congreso Geológico Argentino, Actas II, 339-46.

ARCHANGELSKY, S. 1967. Estudio de la Formación. Baqueró, Cretácico inferior de Santa Cruz, Argentina. Revista Museo de La Plata (n.s.) Paleontología, 63-171.

ArChangelsky, S. \& ARChANGELSKy, A. 2002. Paleobotánica y palinología del Mesozoico. In Geología y Recursos Naturales de Santa Cruz (ed. M. H. Haller), pp. 407-20. Relatorio del XV Congreso Geológico Argentino II-3.

ARCHANGELSKY, S. \& DE LA SOTA, E. 1962. Estudio anatómico de un estípite petrificado de 'Osmundites' de edad Jurásica, procedente del Gran Bajo de San Julián, Provincia de Santa Cruz. Ameghiniana 2, 153-74.

Baron, M., Hillier, S., Rice, C. M., CZAPniK, K \& PARNELL, J. 2004. Fluids and hydrothermal alteration assemblages in a Devonian gold-bearing hot spring system, Rhynie, Scotland. Transactions of the Royal Society Edinburgh: Earth Sciences 94, 309-24.

CAlder, M. G. 1953. A coniferous petrified forest in Patagonia. Bulletin British Museum (Natural History), Geology 2, 99-138.

Channing, A. 2003. The Rhynie Chert early land plants: palaeo-ecophysiological and taphonomic analogues. Transactions Institutions of Mining and Metallurgy: Section B Applied Earth Science 112, B170-1.
Channing, A. \& Edwards, D. 2004. Experimental taphonomy: Silicification of plants in Yellowstone hot spring environments. Transactions of the Royal Society Edinburgh: Earth Sciences 94, 503-21.

de Barrio, R. E., Arrondo, O., Artabe, A. \& Petriella, B. 1982. Estudio geológico y paleontológico de los alrededores de la estancia Bajo Pellegrini, Provincia de Santa Cruz. Revista de la Asociación Geológica Argentina 37, 285-99.

ECHAVARRÍA, L. E., SCHALAMUK, I. \& ETCHEVERRY, R. O. 2005. Geologic and tectonic setting of the Deseado Massif epithermal deposits, Argentina, based on El Dorado-Monserrat. Journal of South American Earth Sciences 19, 415-32.

Echeveste, H., Fernández, R., Bellieni, G., Tessone, M., Llambías, E., SchalamuK, I., Piccirillo, E. \& DE MIN, A. 2001. Relaciones entre las Formaciones Bajo Pobre y Chon Aike (Jurásico medio a superior) en el área Estancia El Fénix-Cerro Huemul, zona centrooccidental del Macizo del Deseado, provincia de Santa Cruz. Revista de la Asociación Geológica Argentina 56, 548-58.

FAYERS, S. R. \& TREWIN, N. H. 2004. A review of the palaeoenvironments and biota of the Windyfield Chert. Transactions of the Royal Society Edinburgh: Earth Sciences 94, 325-39.

GNAEDINGER, S. C. 2000. Xilotafoflora de la Formación La Matilde (Jurásico) del Gran Bajo de San Julián, Santa Cruz, Argentina. Parte I: Prototaxoxylon Kräusel y Dolianiti, Mesembrioxylon Seward y Araucarioxylon Kraus. Universidad Nacional del Nordeste, Comunicaciones Cientificas y Tecnológicas 2000. Resumen: B013.

GNAEDINGER, S. C. 2001. Especies de Araucarioxylon Kraus de la Formación La Matilde, Gran Bajo de San Julián, provincia de Santa Cruz, Argentina. Ameghiniana Suplemento Resúmenes 38, 34R.

GNAEDINGER, S. C. 2004. Estudio preliminar de la xilotafoflora de la Formación La Matilde (Jurásico Medio) del Gran Bajo de San Julián, Santa Cruz, Argentina. Universidad Nacional del Nordeste, Comunicaciones Cientificas y Tecnológicas 2004. Resumen: B-019.

Guido, D., DE BARrio, R. \& SchalamuK, I. 2002. La Marciana Jurassic sinter - implications for exploration for epithermal precious-metal deposits in the Deseado Massif, southern Patagonia, Argentina. Transactions of the Institution of Mining and Metallurgy: Section B: Applied Earth Science 111, B106-13.

Guido, D., DE LuPI, R., LOPEZ, R., DE BARRio, R. \& SCHALAMUK, I. 2002. Estromatolitos y mineralización epitermal en el área Marianas-Eureka, sector occidental del Macizo del Deseado, Santa Cruz. XV Congreso Geológico Argentino, Actas II, 284-9.

Herbst, R. 2003. Osmundacaulis tehuelchense nov. sp. (Osmundaceae, Filices) from the Middle Jurassic of Santa Cruz province (Patagonia, Argentina). Courier Senckenberg Forschungs Institut 241, 8595.

Herbst, R. \& SAlazar, E. B. 1998. Revisión de la flora matildense del Gran Bajo de San Julián, provincia de Santa Cruz, Argentina. Facena 14, 7-24.

Herbst, R., Lutz, A. L., Gallego, O. F. \& Acevedo, E. B. 1995. El bosque petrificado del Gran Bajo de San Julián, provincia de Santa Cruz, Argentina. Ameghiniana 32, $101-7$. 
Hibbett, D. S., Donoghue, M. J. \& Tomlinson, P. B. 1997. Is Phellinites degiustoi the oldest homobasidiomycete? American Journal of Botany 84, 1005-11.

IBÁÑEZ, C. \& ZAMUNER, A. B. 1996. Presence of Hyphomycetes (Deuteromycetes) in cones of Araucaria mirabilis (Spegazzini) Windhausen, Middle Jurassic of Patagonia. Mycotaxon 59, 137-43.

LESTA, P. \& FERELLO, R. 1972. Región extraandina de Chubut y norte de Santa Cruz. In Geología regional Argentina (ed. A. F. Leanza), pp. 601-53. Academia Nacional de Ciencias, Córdoba.

Lopez, R., Guido, D., SchalamuK, I. \& DE BARrio, R. E. 2003. Las Margaritas, un sinter Jurásico vinculado a mineralizaciones auríferas del noroeste del Macizo del Deseado, provincia de Santa Cruz, Argentina. Actas X Congreso Geológico Chileno, p. 9.

Marchionni, D. S., DE BARrio, R. E., Tessone, M. O., DeL Blanco, M. A. \& Echeveste, H. J. 1999. Hallazgo de estructuras estromatolíticas jurásicas en el Macizo del Deseado, provincia de Santa Cruz. Revista de la Asociación Geológica Argentina 54, 173-6.

Moreira, P., FERnÁndez, R., SCHALAMUK, I. \& ETCHEVERRY, R. O. 2002. Depósitos carbonáticos de hot spring relacionados a manifestaciones epitermales (Au-Ag), Distrito La Josefina. Macizo del Deseado. Provincia de Santa Cruz. Actas del XV Congreso Geológico Argentino II, 324-9.

Moreira, P., FERnÁndeZ, R., ECHEVESTE, H. \& SCHALAMUK, I. 2005. Las manifestaciones epitermales en el área del Cerro Contreras, Macizo del Deseado, Provincia de Santa Cruz. Relatorio del XVI Congreso Geológico Argentino, Actas II, 249-56.

Pankhurst, R. J., Leat, P. T., SRUOGa, P., Rapela, C. W., Marquez, M., Storey, B. C. \& Riley, T. R. 1998. The Chon Aike province of Patagonia and related rocks in West Antarctica: A silicic large igneous province. Journal of Volcanology and Geothermal Research 81, 113-36.

PANTElEYEV, A. 1996a. Hot-spring Au-Ag, In Selected British Columbia Mineral Deposit Profiles, Volume 2 Metallic Deposits (eds D.V. Lefebure \& T. Hõy), pp. 33-6. British Columbia Ministry of Employment and Investment, Open File 1996-13.

PANTELEYEV, A. 1996 b. Epithermal Au-Ag: Low sulphidation, In Selected British Columbia Mineral Deposit Profiles, Volume 2 - Metallic Deposits (eds D.V. Lefebure \& T. Hõy), pp. 41-4. British Columbia Ministry of Employment and Investment, Open File 1996-13.
PANZA, J. L. \& HALleR, M. J. 2002. El volcanismo Jurásico. In Geología y Recursos Naturales de Santa Cruz (ed. M. J. Haller), pp. 89-101. Relatorio del XV Congreso Geológico Argentino, Actas I.

RILEY, T. R. \& LEAT, P. T. 1999. Large volume silicic volcanism along the Gondwana proto-Pacific margin: lithological and stratigraphical investigations from the Antarctic Peninsula. Geological Magazine 136, $1-16$.

Riley, T. R., Leat, P. T., PAnkhurst, R. J. \& Harris, C. 2001. Origins of large volume silicic volcanism in the Antarctic Peninsula and Patagonia by crustal melting. Journal of Petrology 42, 1043-65.

SCHALAMUK, I., ZUBIA, M., GENINI, A. \& FERNÁNDEZ, R. R. 1997. Jurassic epithermal $\mathrm{Au}-\mathrm{Ag}$ deposits of Patagonia, Argentina. Ore Geology Reviews 12, 173-86.

SCHALAMUK, I., DE BARRIO, R., FERnÁNDEZ, R. \& GUIDO, D. 1999. Hot spring structures from El Macanudo-El Mirasol area, Deseado Massif, Argentina. In Mineral Deposits: Processes to Processing, I (eds C. J. Stanley et al.), pp. 577-80. Rotterdam: A.A. Balkema.

Stipanicic, P. \& Reig, A. 1957. El Complejo Porfírico de la Patagonia Extrandina y su fauna de anuros. Acta Geológica Lilloana, Tucumán 1, 185-297.

StOcKeY, R. A. 1975. Seeds and embryos of Araucaria mirabilis. American Journal of Botany 62, 856-68.

STOCKEY, R. A. 1977. Reproductive biology of the Cerro Cuadrado (Jurassic) fossil conifers: Pararaucaria patagonica. American Journal of Botany 64, 73344.

StOckeY, R. A. 1978. Reproductive biology of the Cerro Cuadrado fossil conifers: Ontogeny and reproductive strategies in Araucaria mirabilis (Spegazzini) Windhausen. Palaeontographica B166, 1-15.

Trewin, N. H. 1994. Depositional environment and preservation of biota in the Lower Devonian hot-springs of Rhynie, Aberdeenshire, Scotland. Transactions of the Royal Society Edinburgh: Earth Sciences 84, 43342.

TREwIN, N. H. 1996. The Rhynie Cherts: an early Devonian ecosystem preserved by hydrothermal activity. In Evolution of hydrothermal ecosystems on Earth (and Mars?) (eds G. R. Bock \& J. Goode), pp. 131-49. Ciba Foundation Symposium 202.

Zamuner, A. B. \& FAlASCHI, P. 2005. Agathoxylon matildense n. sp., leño araucariaceo del Bosque Petrificado del cerro Madre e Hija, Formación La Matilde (Jurásico medio) provincia Santa Cruz, Argentina. Ameghiniana 42, 339-46. 